\title{
1. Performance requirements and investment incentives: an overview
}

The purpose of this introductory chapter is to offer a broad picture of the types of performance requirements and investment incentives that are typically used by host states and in so doing also provide a deeper understanding of many of the economic concerns that are raised in conjunction with these instruments. This chapter is divided into two parts, following the structure of the book: the first covers performance requirements, and the second deals with investment incentives. Again, this should not be taken to convey that these two varieties of policy tools necessarily operate in isolation: they are often employed by host states in tandem. Nor does this separation imply that the same measure cannot simultaneously be construed as both a performance requirement (an impediment on FDI) and as an investment incentive (a stimulus for FDI). One of the central themes of this chapter, and indeed of this book as a whole, is that it is exceedingly difficult to establish discrete definitions of these concepts, a reality that often exacerbates both identifying as well as regulating these kinds of measures.

\section{PERFORMANCE REQUIREMENTS}

\section{(i) Definitions and Categories}

There is no universally adopted definition of performance requirements. Some materials describe performance requirements as all "host state control techniques on operational level". ${ }^{1}$ Other studies referred to them simply as "host country operational measures". ${ }^{2}$ These definitions reflect an understanding of performance requirements as a variety of regulatory measures imposed by host state governments on the activities of foreign

1 C. Wallace, The Multinational Enterprises and Legal Control (2nd edn, Kluwer Law International, The Hague 2002) 326.

2 'Host Country Operational Measures' (UNCTAD, 2001) <http:// unctad.org/en/docs/psiteiitd26.en.pdf> accessed 11 June 2014. 
multinational enterprises (MNEs) within its territory. Performance requirements are therefore conditions which host countries impose on MNEs, requiring them to meet certain specified goals with respect to their business activities in the host country. ${ }^{3}$ Indeed, they are often termed "conditional investment incentives", a phrase which can also be applied to relocation incentives within states implemented by subnational governments. At a very general level, performance requirements are intended to oblige MNEs to conduct their investment activities in ways considered beneficial for the host state's economy. ${ }^{4}$ Much as there is no commonly accepted definition of performance requirements, there is also, perhaps somewhat more problematically, no exhaustive list of what type of measures would be captured by such a definition. A wide range of foreign investment regimes exist from country to country in accordance with their investment policies and developmental strategies. Performance requirements could take the form of various conditions imposed upon the mode of the foreign investor, such as a joint venture with a local partner or a requirement that they possess a certain quantity of foreign capital to fund their operations. In the post-establishment stage of investment, performance requirements could dictate the way the foreign investor undertakes its commercial activities within the territory of the host state. This could include, for example, rules relating to the use of domestic materials and inputs in manufacturing or that a certain amount of production is exported. Local content-based performance requirements are one of the most commonly used performance requirements. ${ }^{5}$ Such measures have been widely used by some of the emerging market countries such as Indonesia, India, Malaysia, China, Brazil, Argentina, and others in the automotive industry. ${ }^{6}$ Generally speaking, performance requirements have been used extensively by many countries at different stages of development. The incidence of performance requirements have varied across countries, depending upon their development strategy, their endowments of natural resources as well as skilled labour, and the market size of the host state.

3 'Foreign Direct Investment and Performance Requirements: New Evidence from Selected Countries' (UNCTAD, 2003) iii <http://unctad.org/en/Docs/ iteiia20037_en.pdf> accessed 6 June 2014.

4 'World Investment Report. FDI Policies for Development: National and International Perspectives' (UNCTAD, 2003) 119 <http://unctad.org/en/Docs/ wir2003light_en.pdf $>$ accessed 5 June 2014.

5 UNCTAD (n 3 ) 7.

6 ibid. 13. 
The United Nations Conference on Trade and Development (UNCTAD) divides performance requirements into three categories, based on the way in which they are regulated under international law: the first consists of those which are explicitly prohibited by the WTO Agreement on Trade Related Investment Measures (TRIMs) because they are inconsistent with Articles III (national treatment) and XI (prohibition on quantitative restrictions) of GATT 1994; the second includes requirements that are explicitly prohibited, conditioned or discouraged by interregional, regional or bilateral (but not by multilateral) agreements, typically concerning investment but also found in regional trade and economic integration agreements; and the third category covers requirements that are not subject to control by either the WTO or under any IIA, because they address social, environmental or other public-interest concerns. $^{7}$

Local content rules which mandate that firms use a specific percentage of local materials are among the most popular performance requirements. Such measures have been used by a wide range of developed and developing states for decades as part of the strategy for assisting domestic industry by providing ready markets for their manufactured goods. ${ }^{8}$ Similarly, a product mandate requirement compels an investor to manufacture a specific product that may be of economic interest to the host state. This can result in an increase in exports if there is insufficient demand in the local market for the mandated product. 9 Some states impose laws that are aimed at artificially increasing exports. A foreign investor subject to an export requirement must export a certain amount or percentage of its production, normally ascertained either by value (as a percentage) or by quantity (numerically or by weight). This has the potential advantage of freeing up local firms to serve internal markets, possibly with more lucrative returns. Export performance requirements also attempt to guarantee that the foreign currency earned by the host state as a consequence of the presence of the foreign investor exceeds the revenues which foreign investors earn through their sales on local markets. ${ }^{10}$ Though not as widespread as local content rules, export

7 UNCTAD generally (n 3).

8 G.C. Hufbauer and J. Schott, Local Content Requirements: A Global Problem (Peterson Institute for International Economics, Washington DC 2013).

9 R. Edwards and S. Lester, 'Towards a More Comprehensive World Trade Organization Agreement on Trade Related Investment Measures' (1997) 33 Stanford Journal of International Economic Law 169, 202.

10 M. Sornarajah, The International Law on Foreign Investment (3rd edn, CUP, Cambridge 2012) 205. 
performance requirements have been implemented by some newly industrializing countries as a consequence of the shift in their developmental strategy from manufacturing within the country (a strategy itself which was aimed at reducing reliance on imports) towards securing profits by means of export of goods. ${ }^{11}$ Such export-oriented developmental strategy can be seen, for example, in some of the Association of Southeast Asian Nations (ASEAN) states, which initially concentrated on importsubstituting industrialisation, gradually transitioning to export-oriented industrialisation. Similar to export and local content requirements are trade-balancing performance requirements. These are restrictions placed on foreign investors which limit the amount of purchases or use of imported products by foreign MNEs to a proportionate amount of the volume or value of local products that the company exports. ${ }^{12}$ They also restrict the importation by an enterprise of products which are used in, or related to, its local production in general or to an amount related to the volume or value of local production that it exports. ${ }^{13}$ Such restrictions have the effect of compelling firms to use local substitutes.

Price controls are another performance requirement that can be placed on foreign firms. These are limits that host states impose on the prices that a foreign investor can charge the public for the products or services that it sells. The price may be fixed by a governmental ministry or a designated administrative agency for various policy goals, including notably allowing less-competitive local firms to remain viable in a given market. Over time, the costs of labour and other inputs will require that such set prices will have to be re-assessed in order for the investment to remain profitable, such that foreign investors may find themselves in a constant state of renegotiation. Transfer pricing - the prices charged between affiliates for commodities or services - may also be subject to host-state regulation. ${ }^{14}$ This has the effect of apportioning a foreign firm's income tax to the host state rather than to another jurisdiction.

Local equity requirements mandate that local investors hold a certain percentage ownership of a company created by foreign investment. Such performance requirements may take the form of other financial restrictions including minimum equity requirements, prescribed debt equity ratios, limits of profit repatriation, requirements for reinvestment of profits and prohibitions on financing from local sources. In a similar

\footnotetext{
ibid. 111.

TRIMs Agreement, Annex, 1(a).

ibid. 2(a).

J. Salacuse, The Three Laws of International Investment (OUP, Oxford
} 2013) 104. 
vein, local collaboration rules specify that a foreign firm is permitted to enter the host state only in collaboration with a local partner, allowing local firms to benefit from the commercial expertise and profitability of the foreign partner. This type of performance requirement was used by many developing countries, including Eastern European states during the Communist era and prior to the formal installation of free market economics. ${ }^{15}$ The use of local collaboration with a state entity allowed socialist states, which saw the benefits of foreign investment by MNEs, to combine their theory of economic governance with the expansionary capitalistic strategy of FDI. This model proliferated to the communist states in Asia such as China, Vietnam, Laos and Cambodia. ${ }^{16}$ Another way in which local equity requirements can be imposed on foreign multinationals is through requiring the establishment of a joint venture with local firms. These have remained popular in Asia. Requirements which advantage firms owned by nationals (or particular ethnic groups) are referred to as indigenization measures.

Minimum capitalization performance requirements are controls implemented by the host state demanding that the foreign investor should bring in all or a certain percentage of their capital from abroad, rather than raising it from local sources. This can help ensure that there is a sufficient quantity of local capital to invest in domestic firms. In a related fashion, host states can ensure that there is sufficient capital available in domestic banks for future re-investment by restricting or limiting the repatriation of profits. This is achieved via various tools, including taxing remitted dividends, limiting debt: equity ratios, and restricting the use of various types of equipment. Foreign exchange controls, which can also be viewed as a kind of performance requirement controlling the conduct of firms, are instigated by countries where the available amount of foreign currency is limited. Limiting a foreign firm's capacity to repatriate profits can significantly impact on its profits. ${ }^{17}$

Employment and training requirements may also be imposed on foreign firms. This could involve a quota of host country nationals being employed, or might require a training plan for the development of local personnel so that over time indigenous employees will occupy more positions within the project. ${ }^{18}$ Employment or training requirements have been applied by a number of countries. For example, employment

\footnotetext{
15 Sornarajah (n 10) 106.

16 ibid. 106-7.

17 Salacuse (n 14) 105.

18 ibid.
} 
requirements were introduced in Malaysia in the 1970s with the introduction of the Labour Utilization Relief incentive. It provided increasingly generous tax exemptions for pioneer-status industries the greater the number of full-time employees. Illustrating the intersect with investment incentives, tax deductions for training expenses were given for approved employee training in Malaysia's manufacturing sector in the 1990s in order to raise productivity. In Singapore, the Skills Development Fund gives financial assistance to companies for training their workers. ${ }^{19}$ In a similar fashion, host states may instigate management controls to ensure that the managers or other employees of the investment project will encourage the transfer of expertise and technology. Mandatory technology transfer is itself a leading form of performance requirement, although unlike conventional employment and training targets, it is less easy to measure.

It must be recognized that host states do not always apply all performance requirements consistently or evenly. Host states may relax some of their demands on foreign investors if the foreign firm undertakes other commitments which may address the country's developmental strategy more effectively, often in conjunction with the imposition of other types of performance requirements. For example, local equity requirements may be relaxed by host states, allowing foreign investors to set wholly-owned enterprises in industries which are of particular interest to the host state. Equity requirements may be suspended if the investor is willing to locate its operations in an underdeveloped region of the host state or if it exports a larger percentage of its manufactured goods. ${ }^{20}$ Given that these strategies allow for the transgression of rules like local equity participation, such policies bear a close resemblance to investment incentives.

\section{(ii) Justifications}

Performance requirements are used to obtain the type of investment that a host state needs for its economic needs, improving the distribution of any gains from FDI towards the host country. Governments tend to impose performance requirements to achieve macro- (the whole country) or micro-economic development (one industry or region) goals or to alter the distribution of benefits among regions or the population at large. This will include not only assisting local firms, providing employment and

19 Z. Boroo, 'Effective Use of Performance Requirements and Investment Incentive' (2012) 17 Mongolian Journal of International Affairs 97.

20 Sornarajah (n 10) 114. 
training but can also address a state's desire to guard against any balance of payment problems caused by the remittance of profits from FDI back to the home state. ${ }^{21}$ As performance requirements do not create unimpeachable barriers to FDI, but simply make it conditional on certain conduct, they are not necessarily hostile to liberalized markets. Indeed, some commentators have suggested that there is nothing inherently unjust about the imposition of economically distortive performance requirements, because promoting the development of the national economy is a valid objective of any government. ${ }^{22}$ Some see them as legitimate tools by which governments seek to distribute the gains engendered by foreign firms more evenly across a broader socioeconomic spectrum. ${ }^{23}$ Most of the literature on the value of performance requirements has focused on the economic effectiveness of these tools to achieve various economic objectives, including GDP and employment. There has been very little emphasis on the potential for performance requirements to advance social or other policy goals, such as the advancement of indigenous peoples or the protection of the environment. ${ }^{24}$

The case for support of trade-related controls on FDI performance requirements essentially amounts to a justification of government intervention in markets. So called "strategic" trade theory suggests that some non-market forces can have a significant positive impact on trade flows in a way that the traditional theories of free trade cannot explain. This is because there are certain key sectors where labour and capital are more productive than other sectors as a consequence of advantages engendered by economies of scale as well as experience and innovation. So some trade-based restrictions on FDI can actually enlarge national income even in situations where the country lacks a comparative advantage in those sectors. Government intervention in the form of restrictions on free trade can accordingly correct market imperfections. ${ }^{25}$

21 P. Muchlinski, 'Policy Issues' in P. Muchlinski, F. Ortino and C. Schreuer (eds), Oxford Handbook of International Investment Law (OUP, Oxford 2008) 32.

22 B. Legum, 'Understanding Performance Requirement Prohibitions in Investment Treaties' (2007) 53 Contemporary Issues in International Arbitration and Mediation 53-4.

23 D. Schneiderman, Constitutionalizing Economic Globalization (CUP, Cambridge 2008) 27.

24 J. VanDuzer, P. Simons and G. Mayeda, Integrating Sustainable Development into International Investment Agreement, (Commonwealth Secretariat, London 2013) 204.

25 Edwards and Lester (n 9) 175-6. 
One example where performance requirements appear to have been economically justified is in support for "infant industries". According to the infant industry theory, developing countries have a potential advantage in manufacturing, but new manufacturing industries in developing countries cannot initially compete with well-established manufacturing in developed countries. This is especially so if the manufacturing sector is faced with direct competition at home in the form of FDI. The economic rationale for governmental intervention in these circumstances is that, over time, per-unit production costs will fall as experience in production increases, enabling the industry's goods to become more competitive in the future. ${ }^{26}$ So by protecting a relatively weak domestic industry from foreign competition at the outset (either via trade or through direct investment), the host-state government allows the industry to accumulate experience in production, ultimately generating productivity gains. The WTO itself has acknowledged that performance requirements could assist in economic development. ${ }^{27}$

Some countries, especially in the developing world, also employ a wide range of performance requirements in order to combat the restrictive business practices used by foreign firms, such as monopolization to control a market or transfer-pricing to distort earnings for tax evasion. This will include empowering specific industries such as manufacturing or high technology, reducing unemployment, augmenting the skills of local workers, promotion of regional development, trade balancing away from imports, technology transfer, and in some cases political independence. ${ }^{28}$ In some circumstances local content, export, and joint venture participation are imposed by host states to mitigate or pre-empt anticompetitive business practices in the form of monopolization, price fixing, cartels and collusive tendering. ${ }^{29}$ It is thought that a number of developing countries resort to performance requirements as a response to the anti-competitive business practices of MNEs, and not necessarily as a means of generating greater domestic resource gains. ${ }^{30}$ Restrictions on

26 ibid. 176.

27 Ministerial Declaration on Doha Work Programme, adopted at Hong Kong, 18 December 2005, Annex F (WT/MIN(05)/DEC).

28 UNCTAD (n 3) 6.

29 H. Puri and P. Brusick, 'Trade-related investment measures: Issues for developing countries in the Uruguay Round', Uruguay Round: Papers on Selected Issues (1989) UNCTAD/ITP/10, cited in UNCTAD ibid.

30 V. Mosoti, 'The WTO Agreement on Trade-Related Investment measures and the Flow of Foreign Direct Investment in Africa: Meeting the Development Challenge' (2003) 15 Pace International Law Review 181, 195. 
the size or the structure of foreign firms can render them less capable of exerting monopolistic influences on markets, ultimately harming consumers. To the extent that these types of performance requirements are effective, they may be seen to operate as a suitable alternative to the lack of international cooperation in competition law. Likewise, some developing countries in particular have argued that trade-oriented performance requirements consisting of export obligations and foreign currency exchange neutrality are needed to moderate the adverse effects of capital outflows associated with balance-of-payment problems linked to trade deficits. ${ }^{31}$ This justification appears more credible in light of some of the problems of capital flight associated with incidents such as the Asian financial crisis of the late 1990s and echoed in warnings issued by the IMF during the global financial crisis.

Studies have demonstrated that local content requirements can be a useful tool for economic growth, although this may depend on the specific conditions of their application in each context. ${ }^{32}$ Beneficial effects have been observed when these tools are used in conjunction with offsetting measures designed to ensure that local firms continue to face some competitive pressures and still have access to technology and skills to improve their capabilities. Local content, when coupled with technology transfer rules, may promote the establishment of industrial linkages with suppliers and consumers, assisting in the development of the host state's economy. Without these requirements, foreign firms would be more likely to source their production inputs from abroad, which could undermine the establishment of beneficial local clusters in host states. ${ }^{33}$ For their part, export-oriented requirements were imposed on foreign firms because of the inability of the import-substitution model of industrialisation to generate consistent growth in manufacturing output and employment. Numerous studies demonstrated that importsubstituting industrialisation was inefficient whereas, export-oriented strategies were economically advantageous. Export performance requirements safeguard the domestic market for local firms. In the absence of export performance requirements, local firms have to compete with foreign multinationals which sell their goods domestically and which are often able to produce goods at a lower cost. The emerging local industry

\footnotetext{
31 India's submission to the WTO: WT/WGTI/W/152 (19 November 2002).

32 UNCTAD (n 3).

33 K. Singh, 'India. Foreign Investors' Paradise: The Devastating Impacts of the EU-India Free Trade Agreement' (Global Research, 2011) <www. globalresearch.ca/india-foreign-investors-paradise-the-devastating-impacts-of-the -eu-india-free-trade-agreement/23036> accessed 12 June 2014.
} 
is at risk of being suppressed without such controls. In this way, the avoidance of the crowding-out effect is another justification for export performance requirements. ${ }^{34}$ Export-oriented industrialization strategies resulted in remarkable growth in Asian economies including Malaysia and the Philippines. ${ }^{35}$

The purpose of minimum capitalization performance requirements is to preclude multinational corporations from exhausting capital that may be available through the host state's domestic financial institutions, freeing up domestic capital for domestic uses. Accordingly, in the absence of such restrictions, if the foreign firm is permitted to raise capital on local markets, local funds would be depleted in satisfying the needs of the foreign investor instead of being directed at local projects that might more clearly favour the host state or public interest. ${ }^{36}$ In other words, if host states did not impose capitalization requirements on incoming foreign investors, it is quite possible that one of the main benefits of FDI, namely capital inflows to host country, would be nullified. ${ }^{37}$ The IMF's acceptance of a wide range of capital controls as a legitimate buttress against rapid capital inflows, both of which have the potential to destabilize an economy, is evidence of support for this variety of performance requirement. ${ }^{38}$

Local equity performance requirements can serve a number of purposes including allowing parties to pool resources and technological competences. They also permit the diversification of risks associated with the project. Joint ventures formed between foreign and domestic investors may conduct their business activities in a manner that is more economically beneficial to the host state than that of a wholly foreign owned enterprise. For example, an MNE with foreign affiliates may be more likely to import a greater proportion of raw materials and other production inputs than necessary, simply because these firms are more familiar with foreign suppliers than they are with local suppliers. Foreign affiliates might suffer from a lack of information on the capabilities of local suppliers. The presence of a local partner in a joint venture could

34 Sornarajah (n 10) 206.

35 T.K. Wie, 'Export-Oriented Industrialisation and Foreign Direct Investment in the ASEAN Countries' in E. Aryeetey and ors (eds), Asia and Africa in the Global Economy (United Nations University Press, Hong Kong 2003).

36 Sornarajah (n 10) 108.

37 ibid.

38 'The Liberalization and Management of Capital Flows: An Institutional View' (International Monetary Fund, 14 November 2012) <www.imf.org/ external/np/pp/eng/2012/111412.pdf> accessed 2 December 2014. 
assist in overcoming these information gaps concerning the potential of local suppliers. ${ }^{39}$ Perhaps most importantly, a joint venture with a local partner would be more inclined to undertake research and development to establish new technologies. Such arrangements may accordingly be viewed as more advantageous in terms of fostering local skills and know-how which may be of long term benefit to host states. Imposition of the requirement of entry via a joint venture enables the more efficient transfer of technology and management, capturing the traditional benefits of FDI. Joint ventures are believed to benefit the host state more so than other structures because they ensure that only a minor portion of the MNE's revenues are repatriated overseas. ${ }^{40}$

Furthermore, equity joint ventures between foreign and local enterprises make it possible to preserve local managerial control over the business with the participation of foreign multinationals. Some joint venture laws go beyond simply local equity rules, in that the local partner not only owns a share of the joint venture but also participates in its management, ensuring greater control over the investment. Of course use of joint ventures does not guarantee local control, as local managers may sometimes be unable to manage the project effectively. Even in these situations, joint ventures are believed to facilitate the improvement of domestic managerial skills and knowledge. ${ }^{41}$ Likewise, employment and training requirements placed on foreign firms aim not only to reduce local unemployment, but also to induce foreign investors to engage more actively in training and human resource development activities and to encourage the expansion of skill-intensive operations. More complete and rewarding employment can result in both tangible economic gains as well as less measurable social improvements.

At a more general level, the need to regulate MNEs through performance requirements has arisen because a significant portion of FDI in the developing world has been in the extractive industries, leading to issues of natural resources depletion and the possibility of environmental damage. ${ }^{42}$ This may be one reason why developing countries are convinced that imposition of performance requirements, dictating the nature

39 UNCTAD (n 3) 99-100.

40 C.B. Choi and P. Beamish, 'Resource Complementarity and International Joint Venture Performance in Korea' (2013) 30:2 Asia Pacific Journal of Management 561.

${ }^{41}$ P. Muchlinski, Multinational Enterprises and the Law (2nd edn, OUP, Oxford 2007) 191-2.

42 Wallace (n 1) 326. 
and extent of commercial activities, enhances the value of FDI. ${ }^{43}$ It is often pointed out that since developed countries adopted performance requirements during their periods of industrialization, developing countries should have the right to use the same tools as they seek to diversify their economies. ${ }^{44}$ This is precisely why a number of commentators view the efforts of developed countries to prevent the use of performance requirements as unfair, because such policies were among the tools used by these countries to achieve prosperity in the first place. ${ }^{45}$ The use of these policies by developed states during their periods of industrialization along with their subsequent removal and prohibition, has been condemned by some for its apparent hypocrisy. In this regard, conditioning the acceptance of inward FDI in extractive sectors on the provision of infrastructure appears to have been a useful policy for some developing states. For instance, China is widely recognized to have provided significant transportation facilities for many African states as a condition of its FDI. ${ }^{46}$

The purpose of ownership-based controls on foreign investment, such as those encouraging indigenous ownership and those requiring joint ventures, are thought to contribute to the emergence of a local "entrepreneurial class", ${ }^{47}$ which may have social as well as economic benefits. Such measures seek to ensure that foreign investors contribute to the economic advancement of groups which may have been traditionally disadvantaged. If FDI benefits are enjoyed solely by elite groups within the host state, this could lead to increased inequality and ultimately engender social tension. Ethnicity may be taken into consideration when host states determine the nature of permissible FDI within its territory. In Malaysia, for example, there is a prescribed structure of shareholdings, where preference is given to indigenous Bumiputera people of Malaysia. ${ }^{48}$ South Africa implemented its Black Economic Empowerment programme in order to spur the advancement of a particular racial group. This led to tensions with some foreign investors

43 Sornarajah (n 10) 205.

44 ibid. 206.

45 E.g. H.J. Chang, Bad Samaritans: Rich Nations, Poor Policies and the Threat to the Developing World (Random House, London 2007) 84-103.

46 See e.g. U. Ofodile, 'Trade, Empires, and Subjects - China-Africa Trade: A New Fair Trade Arrangement or the Third Scramble for Africa' (2008) 41 Vanderbilt Journal of International Law 505.

47 S. Picciotto, Regulating Global Corporate Capitalism (CUP, Cambridge 2011) 163.

48 ibid. 107. 
who suffered regulatory discrimination as a consequence of the policy, which arguably had a legitimate social justification. ${ }^{49}$ While such types of performance requirement may invite conflict with foreign firms, such measures may become less invasive once the process of indigenization has been completed and the visible dominance of foreign investment has diminished. 50

\section{(iii) Criticisms}

Despite the fact that many developed countries used performance requirements in the past, many are reluctant to accept the right of developing countries to use performance requirements on the grounds that they distort international trade, ${ }^{51}$ associating these tools with ineffectual statist interventionism. ${ }^{52}$ The damaging effect of performance requirements is believed to be one of the reasons that most nations around the world favoured direct stimulus packages in order to address the global financial crisis of 2008-09 rather than via discriminatory trade provisions. ${ }^{53}$ In the long term, trade-based performance requirements have are thought to be damaging to both the MNEs as well as the host states which impose them. Trade-related performance requirements distort international trade flows, undermining the welfare effects of free trade. 54 UNCTAD's World Investment Report has in the past indicated that the economic advantages of performance requirements are not clearly empirically demonstrated. ${ }^{55}$

Commentators have distinguished between protections in IIAs that are rooted in concepts of natural justice, like the fair and equitable treatment standard or the guarantee against expropriation without investment, and prohibitions on performance requirements, which are grounded upon

49 Piero Foresti, Laura de Carli \& Others $v$ The Republic of South Africa ICSID Case No. ARB(AF)/07/01.

50 Sornarajah (n 10) 114.

51 ibid. 206.

52 UNCTAD (n 3) iii.

53 R. Leal-Arcas, International Trade and Investment Law (Edward Elgar, Cheltenham 2010) 19-20.

54 C. Fontheim and M. Gadbaw, 'Trade Related Performance Requirements Under the GATT-MTN System and US Law' (1982) 14 Law \& Policy of International Business 129, 139.

55 UNCTAD World Investment Report 2014, 112 (linking performance requirements with investment incentives) <http://unctad.org/en/Publications Library/wir2014_en.pdf> accessed 2 December 2014. 
economic efficiency. ${ }^{56}$ Indeed performance requirements are often criticized as an unwarranted interference in the process of economic decision-making by investors, resulting in an inefficient allocation of resources. Performance requirements accordingly represent a deadweight cost on production that can impose significant burdens on foreign investors and traders. ${ }^{57}$ To frame this allegation in more simple terms, if it was profitable for a firm to engage in the behaviour that was required by the performance requirement, then the firm would do so of its own accord. Alternatively, if the investor does not wish to behave in the manner dictated by the performance requirement, then it can be inferred that the performance requirement is inefficient, imposing an unnecessary cost on economic activity. ${ }^{58}$ Of course, this view presumes that the firm and the government have interests (as well as understandings of efficiency) that are aligned, which may not always be the case. Performance requirements are seen as fundamentally inconsistent with the principle of liberal markets. ${ }^{59}$ Generally speaking, where applied in a protectionist manner, with limited competitive stress, performance requirements can result in inefficient suppliers that burden consumers with high prices and low quality goods or services. ${ }^{60}$ This is why they have largely been abandoned in favour of more widespread acceptance of liberalization. ${ }^{61}$

The conventional case against trade-based performance requirements, as well as against trade and protectionism generally, is derived from the theory of comparative advantage and the resulting gains from international trade. Successive generations of economists have elaborated on the simple model of comparative advantage originally articulated by David Ricardo in the early nineteenth century. ${ }^{62}$ These affirm the basic conclusion that both national and global welfare are maximized when governments allow market forces to direct trade flows. ${ }^{63}$ The same theory could be applied to the flows of FDI. Liberalizing the movement of

56 Legum (n 22) 57.

57 D. Rodrik, 'Economics of Export Performance Requirements' (1987) 102:3 Quarterly Journal of Economics 633.

58 VanDuzer et al. (n 24) 194.

59 R. Dolzer and C. Schreuer, Principles of International Investment Law (2nd edn, OUP, Oxford 2012) 90 and Edwards and Lester (n 9) 170.

60 UNCTAD, World Investment Report 2002: Transnational Corporations and Export Competitiveness at 169 <http://unctad.org/en/Docs/wir2001_en.pdf> accessed 2 December 2014.

61 Schneiderman (n 23) 27.

62 D. Ricardo, Principles of Political Economy and Taxation (John Murray, London 1821) ch. 7.

63 Edwards and Lester (n 9) 174-5. 
capital allows it to be channelled to the places where it can be put to the most productive use, generating wealth and income that can then be used as a basis for further production and trade. In addition to its role as a complementary strategy to trade, FDI is often viewed as an alternative to trade where tariffs and other trade barriers are prohibitive. Marketseeking firms locate in foreign states so that their products are no longer considered as exports. ${ }^{64}$ This objective is frustrated when there are trade-based performance requirements linked.

For example, local content rules can diminish the value of the investment because the production of goods comes at an increased cost which may not be fully recovered through price increases. The host state may gain from the imposition of a local content requirement on a foreign firm because this transfers wealth to local producers which may not otherwise be able to survive in the global marketplace. But this can lead to an unhealthy dependence in case the foreign investor leaves the jurisdiction, which may often be the case where performance requirements become too onerous (often necessitating other precautionary performance requirements such as capital controls). In some cases, local content requirements will induce foreign firms to increase their own domestic production of the component input and induce capital flows and in so doing advance the process of industrialization of the host country. ${ }^{65}$ Local content requirements may also suppress economic development. While such requirements can result in immediate sales for the domestic industry, this industry is also shielded from the beneficial effects of competition, which can be harmful in the longer term. It is also linked to corruption and delays. ${ }^{66}$ The foreign firm using mandatory local components is unable to obtain high-quality, low-priced equivalents from other countries, and consequently will be less able to produce internationally competitive finished products. Accordingly, the domestic industry can hope to achieve import substitution, but the likelihood of further development is low. ${ }^{67}$ Some studies have shown that local content requirements can actually reduce local employment, undermining one of a government's main objectives in encouraging FDI. Foreign investors

64 E.g. K. Reinert, An Introduction to International Economics (CUP, Cambridge 2012) 141-8.

65 Boroo (n 19).

66 C. Cimino, G. Hufbauer and J. Schott, 'A Proposed Code to Discipline Local Content Requirements' (Peterson Institute for International Economics, February 2014) 3 <www.piie.com/publications/pb/pb14-6.pdf> accessed 2 December 2014.

67 (METI, 2010) Boroo (n 19) 101. 
will seek to reduce costs associated with more expensive local inputs through automation or by shifting manufacturing to other jurisdictions. ${ }^{68}$

Local content requirements are not always feasible where the imposing state lacks sufficient capacity to satisfy the needs of foreign investors. This has been a persistent problem for Brazil, which traditionally imposed requirements on foreign oil companies to use facilities such as platforms and ships that are constructed locally, while being unable to supply these in sufficient quantity and size. This may lead to delay or even the abandonment of lucrative FDI projects. ${ }^{69}$ Local content requirements may be further inefficient because locally produced components in a manufacturing process may not meet standards for export to more rigorously regulated markets. They may also be more expensive than better quality materials produced elsewhere. This can be harmful for manufacturers because the companies adhering to the local content rule may not able to produce goods which can be sold in all markets. Some moderately industrialized developing countries, notably Thailand, were able to adapt to prohibitions on local content rules and even thrive in their absence. Local content rules in Thailand's automobile sector had been imposing unrealistic costs and entrenching inefficient suppliers. ${ }^{70}$

Requirements which mandate that an investor source more inputs locally than the investor would have done otherwise can be detrimental not only to the foreign firms on which they are imposed but also to the host state. This is because, in the absence of local competitive pressures, such rules remove the incentive for local firms to produce materials which would be competitive on a world market, resulting in a short-term transfer of wealth to the host state if the investor decides to leave the jurisdiction. Local content requirements could further result in a decrease in imports into the country applying the requirement because domestic equivalents are used. Such restrictions can therefore have a harmful knock-on effect for suppliers in other jurisdictions, causing scaled-back production and associated negative externalities. ${ }^{71}$

68 C. Davidson, S. Matusz and M. Kreinin, 'Analysis of Performance Standards to Direct Foreign Investments' (1985) 18:4 Canadian Journal of Economics 876.

69 J. Leahy, 'Brazil Oilfield Reveals Local Sourcing Problem' Financial Times (London, 30 June 2011).

70 K. Natsuda and J. Thorburn, 'Industrial Policy and the Development of the Automotive Industry in Thailand' (2013) 18:3 Journal of the Asia Pacific Economy 1.

71 Legum (n 22) 53. 
Export requirements, which compel firms to export a given amount of production, are thought to be among the most trade-distorting of all trade-oriented performance requirements. As they often lead to excess supply, these rules can promote dumping in the investor's home market and disrupt trade flows to third countries. Export minima will most likely lead to a higher level of exports from the country applying the rule than would have occurred otherwise, possibly leading to supply shortages and price increases within the domestic market. Foreign firms may have difficulty satisfying the host states' export performance requirements because MNEs often adopt a policy of forbidding export by their subsidiaries into each other's territories. ${ }^{72}$ Relatedly, product mandate requirements can result in an increase in exports if there is insufficient demand in the local market for the mandated product. It could also lead to unsold inventory. ${ }^{73}$ Export bans, which set maximum levels of export, artificially reduce the supply of goods, inflating prices on global markets and potentially leading to harmful price instability. ${ }^{74}$

Non-trade-based performance requirements may also be harmful to firms as well as states. Requirements placed on foreign investors mandating local partnership with domestic firms which may offer little in the way of genuine expertise, know-how or risk-diversification represent significant barriers to entry for foreign firms. Problems arising from poor coordination and uneven information sharing between foreign and local partners have been identified in some situations. ${ }^{75}$ The artificial nature of mandatory joint venture arrangements has seen situations where foreign firms engage in evasive strategies such as the creation of "silent partnerships" with local shell companies. Local partners create companies then let them to foreign managers in order to satisfy local ownership requirements, with the local owner having no control whatsoever over the business. Such practices cause host governments to waste resources on monitoring and enforcement. ${ }^{76}$ The impact of a local equity requirement on the activities of the foreign investor is uncertain because

\footnotetext{
72 Sornarajah (n 10) 112.

73 Edwards and Lester (n 9) 202.

74 E.g. G. Welton, 'The Impact of Russia's 2010 Grain Export Ban' (2011) 11:5 Oxfam Policy and Practice: Agriculture, Food and Land 76.

75 See e.g. R.A. Cramb, 'Palmed Off: Incentive Problems with Joint Venture Schemes for Oil Palm Development on Customary Land' (2013) 43 World Development 84.

76 E.g. in Oman: B. Thomas, 'Omani Firms Face Sanctions for Omanisation Violations' Arabian Business (5 February 2014).
} 
it depends on a large number of variables, including percentage ownership of the local investor and the motivations of the individuals in management, in particular whether they favour local companies when sourcing inputs even where this is unsupported by economic logic. ${ }^{77}$

Mandatory technology transfer could prevent investors from using their technology in host states where they may have done so of their own accord, potentially restricting the more gradual and organic transfer of technology. Restrictions on the remittance of profits may have undesirable effects in the long run, causing MNEs to locate to more investorfriendly jurisdictions and leading to unsatisfied dependencies in the original host state. It is difficult to predict ex ante how a restriction on the remittance of profits may affect trade flows. If profits cannot be remitted, they may be used either to purchase more local goods (which leads to a decline in imports), or to purchase foreign goods as inputs for the manufacturing process (which leads to an increase in imports).

\section{INVESTMENT INCENTIVES}

\section{(i) Definitions and categories}

Investment incentives are simply defined as a non-negative per unit subsidy paid to foreign investors in addition to the regular, marketdetermined rate of return on capital. ${ }^{78}$ Put another way, investment incentives are essentially fiscal contributions intended to influence a company's decision on where to invest. ${ }^{79}$ Incentives tend to be offered to "mobile investors", meaning those that are able to choose the jurisdiction in which they locate, based on regulatory or economic factors rather than the presence of natural resources. Prior to globalization, the jurisdictional competition for direct investment was primarily focused at the subnational level within one state, whereas today this competition has a more international dimension as a consequence of the easy mobility of multinationals. With many more countries in need of FDI than there is available, there is a natural market in which states compete to attract the firms that offer the most in the way of economic advantages. There is a

\footnotetext{
77 Edwards and Lester (n 9) 202.

78 E. Blanchard, 'What Global Fragmentation Means to the WTO' World Trade Organization, Economic Research and Development Statistics (19 December 2013) 17.

79 Edwards and Lester (n 9) 173.
} 
dearth of information about overall spending on FDI incentives, particularly in developing countries. There remain significant barriers to more complete transparency in this regard, many of which are linked to poor governance generally. Ironically these are the very factors which make investment incentives necessary policy tools.

Investment incentives can take the form of subsidies, also known as state aid. The central idea of subsidization or state aid is that it results in a deviation from the normal course of events. Such a "normal" situation is often understood by reference to the market. 80 In that sense the understanding of subsidies (as with investment incentives generally) may be seen as one rooted in competition-based analysis, rather than trade or investment analysis. Regulatory incentives consist of derogations from national or sub-national laws in a manner which is advantageous to the foreign firm. The common understanding of incentive typically does not include broad non-discriminatory policies, such as the provision of general infrastructure or regulatory and fiscal regimes that apply to all sectors. ${ }^{81}$ Regardless of their stage of development, most countries employ a variety of incentives to realize their investment objectives. Subsidies designed to influence the location of investment are a key feature of global competition for FDI. They are used by the vast majority of countries at multiple levels of government, including national, regional and even municipal, and they are applied to a broad range of industries across sectors.

Investment incentives became more popular as tools of economic policy in large developing countries towards the end of the 1990s, as they sought to make themselves more attractive to FDI. ${ }^{82}$ Even where the advantages of investment incentives are not clear, many states may be pressured into offering them because of regulatory competition to attract FDI. ${ }^{83}$ The fear of increased unemployment, especially among highly skilled workers and the crowding-out of domestic firms in equivalent industries have in the past controlled the extent of FDI incentive measures and other initiatives by host states to promote outward FDI. Home country measures to increase outward FDI by assisting in the

80 L. Rubini, The Definition of Subsidy and State Aid: WTO and EC Law in Comparative Perspective (OUP, Oxford 2009) 318.

81 B.V.R. Subrahmanyam, 'Investment Incentives and Multilateral Disciplines' in S.J. Evenett and B.M. Hoekman (eds), Economic Development and Multilateral Trade Cooperation (Palgrave Macmillan and World Bank, New York, NY 2006) 303.

82 Edwards and Lester (n 9) 177.

83 Picciotto (n 47) 163. 
internationalization of domestic firms tend to have privileged exports because the connection between exports and economic growth as well as the capacity for employment and technology acquisition in the home state is more clearly evident.

Investment incentives tend not to occur in isolation but are usually presented in packages, often tailored to suit the particular firm and the needs of the host state. They may be granted in proportion to the size of the project, its importance to the economy or its geographic location within the host state (such as in an underdeveloped region). It is possible for investors to negotiate special agreements in order to secure additional incentives and privileges beyond those specified in the general investment law of the host state. ${ }^{84}$ Importantly, investment incentives are often accompanied by conditions imposed by the host country on the recipient firm. These may be accurately described as performance requirements as discussed above. Indeed, some analysts have used the phrase "performance incentives" to describe this variety of measure, effectively a sub-category of performance requirements imposed on investors. ${ }^{85}$ These contemplate financial or other advantages that flow to investors who meet certain performance standards, often inducing the same type of behaviour that is sought by performance requirements. Investment incentives may also be linked to the host state's achieving a particular policy goal, such as environmental sustainability or technological development. While individual packages with conditions are often negotiated with investors on a case-by-case basis, it is common for FDI incentives to be extended much more broadly, with limited restrictions and across a wide range of economic activity in all sectors. It is important to recognize that some investment incentives may be applicable to all investment whether or not it is domestic or foreign, or they may be applied only to FDI.

Commentators have suggested that there are two main categories of investment incentives: those aimed at increasing the return on an investment project (which would capture tax exemptions, subsidies, and agreements to purchase goods or services); and those aimed at reducing risk, which would include guarantees to provide foreign exchange for debt servicing, international dispute settlement through arbitration, guarantees against nationalization and other protections found in IIAs. ${ }^{86}$ The former may be used predominately by developed states where elemental political risks are low but profits are uncertain, and the latter by

\footnotetext{
84 Salacuse (n 14) 102.

85 Edwards and Lester (n 9) 173.

86 Salacuse (n 14) 100-101.
} 
developing states where political risk represents a major obstacle to internationalization. The former category also appears to be dominated by trade-based incentives whereas the latter is characterized by more traditional investment-oriented ones.

Investment incentives include measures specifically designed either to increase the rate of return of a particular FDI undertaking, or to reduce its costs or other risks, such as those that relate to non-commercial matters like expropriation without compensation. They consist of fiscal incentives such as tax holidays and lower taxes for foreign investors, financial incentives such as grants, preferential loans to multinational corporations and government insurance at preferential rates, as well as other measures like market preferences and stabilization clauses guaranteeing that existing regulations will not change. The provision of subsidized infrastructure, inputs or services can also be seen as incentives. ${ }^{87}$ Since they mitigate some of the risks associated with FDI by providing legal protection to foreign firms, IIAs themselves should be seen as a form of investment incentive.

Taken together, formal FDI incentives and informal FDI promotion initiatives may consist of the following type of measures: improvements to the overall policy framework of the host state, often in conjunction with directed technical assistance from the host state; financial or fiscal incentives such as investment guarantees, insurance, capital or tax relief; preferential market access to the host-state market for goods and services that investors wish to import; the creation of an investment-promotion agency in the host state, with possible discrete external connections in targeted home states, which may include workshops, fairs or information contact points; information exchanges regarding host state investment rules and available opportunities; the more general promotion of linkages between the home and host state; and encouragement of technology transfer between investors and the host state. ${ }^{88}$ Some of these measures as well as activities like attempts to secure the commitment of the home state to provide the host state with technical assistance with the implementation of promotion programmes in the host state - should not strictly speaking be viewed as investment incentives, because they do not necessarily make it easier for specific foreign investment to engage in FDI in the host state; instead, they create a more investor-friendly climate in a more general sense.

\footnotetext{
87 Boroo (n 19).

88 VanDuzer et al. (n 24) 493-4.
} 
Tax incentives and grants are the most common variety of investment incentives for both developed and developing host states. The exemption from various taxes is one of the most common forms of incentive, particularly in developing countries, because these types of incentives appear to cost very little to the host government in the short term. ${ }^{89}$ Income tax relief exempts the investing firm from local income or other taxation for a specified period of time. The host country may also offer exemptions from taxes on dividends, royalty payments, interest payments, property taxes and various other charges for which the project would be otherwise liable. Tax stabilization may also be granted to foreign investors, guaranteeing that the foreign firm will pay no more than a specified minimum tax rate for a predetermined period of time. This is similar to the stabilization clause found in many investment agreements, ensuring that host governments will not alter their laws in a manner that will damage the foreign investor for a certain specified period of time..$^{90}$ Tax-oriented incentives are more sophisticated than traditional investment incentives, in part because they are harder to scrutinize and because their revocation is less confrontational than that of conventional incentives. When the policy approach to FDI is in its downward cycle, the withdrawal of tax incentives for foreign investors tends to be met with less resistance: one of the reasons why this type of reaction against FDI is often described as the "velvet revocation" of incentives. ${ }^{91}$

Technical and business-support-oriented measures are frequently instigated where the host state maintains an investment-promotion agency, and can be deployed in conjunction with other types of incentives or in isolation. These incentives have the purpose of decreasing information asymmetries and administrative burdens associated with a foreign firm's entry into the market of the host country. Technical and business support also facilitates the acquisition of commercial information, such as the location of markets and raw materials. Provision of these types of non-fiscal incentives is often done by investment-promotion agencies. These are an increasingly important component of inward FDI promotional activities. Initially, such bodies were introduced to increase the efficiency of FDI liberalization as a consequence of heavy bureaucratic barriers. They tend to concentrate their efforts on technical issues relating

\footnotetext{
89 Salacuse (n 14) 102.

90 ibid. 101.

91 T. Walde and A. Kolo, 'Coverage of Taxation under Modern Investment Treaties' in P. Muchlinski, F. Ortino and C. Schreuer (eds), Oxford Handbook of International Investment Law (OUP, Oxford 2008) 309.
} 
to the dissemination of information on available investment opportunities as well as administrative procedures. Some even provide "aftercare" once an investor has already invested. Distinct from formal incentive programs, investment-promotion initiatives have been described as "lighthanded public policies to overcome information asymmetries and other market failures" that hinder both inward and outward FDI. Such policies have been advocated by commentators in order to make available information about investment opportunities to MNEs. ${ }^{92}$

Some host state are willing to grant foreign investors a monopoly over the local market by agreeing either to prohibit other similar investments for a specified period of time or to restrict the importation of competing goods through either high tariffs or quotas. ${ }^{93}$ Soft loans are those from the government to private firms at terms more favourable than those obtained on the open market. This type of investment incentive has been very popular, particularly in Japan where a number of these loans have been offered to small and medium-sized enterprises. A similar type of incentive, equity participation by a government involves a financial contribution with a lower expected rate of return than that which would be demanded by private capital markets. This type of investment incentive, popular in some European countries, can be easily disguised through an artificial joint venture. ${ }^{94}$ Lastly, as suggested above, international investment agreements themselves may be seen as a kind of investment incentive, in that they offer investors protections that mitigate the risk of commercial operations overseas. Access to specialized dispute settlement (international arbitration) which is not available to local firms is among the most powerful features of such instruments.

Incentives aimed at stimulating outward FDI have been employed by some countries. This is tied to the recognition that domestic firms must be competitive in international markets as a consequence of the rapid pace of globalization. There has been very limited scholarship on the manner in which states encourage the internationalization of their firms and indeed on the phenomenon of outward FDI itself. ${ }^{95}$

92 T. Moran, 'What Policies Should Developing Country Governments Adopt Toward Outward FDI? Lessons from the Experience of Developed Countries' in K. Sauvant (ed.), The Rise of Transnational Corporations from Emerging Markets (Edward Elgar, Cheltenham 2008) 293.

93 Salacuse (n 14) 102.

94 L. Oxelheim, 'EU-China and the Non-Transparent Race for Inward FDI' (2008) 19:4 Asian Journal of Economics 358.

95 See e.g. D. Collins, BRIC States and Outward Foreign Direct Investment (OUP, Oxford 2013) (noting the recent trend in growth of outward FDI from the 
Developing countries have shown a strong inclination towards the use of investment incentives. ${ }^{96}$ There is now a much greater use of tax incentives to promote research and development initiatives in OECD countries. ${ }^{97}$ In the past 20 years, investment incentives have spread to developing countries where before they had been tools associated only with industrialized countries. Whereas developing countries tend to impose performance requirements on foreign investors to suit their economics needs, investment incentives are a more commonly used tool by developed states. Developing countries may not have sufficient capital or financial means to pay incentives to attract firms, just as they may not have sufficiently developed controls over restrictive business practices under their national laws to curtail anti-competitive behaviour of firms. ${ }^{98}$ Developing countries are more likely to use tax-relief-oriented incentives. Exemptions from corporate income tax, known as "tax holidays", are popular, particularly among developing countries, because they are do not require extensive administration nor do they consume any governmental resources. For their part, developed countries more frequently employ financial incentives such as grants, subsidized loans or loan guarantees. Incentives are a key policy tool for many sub-national governments seeking to attract investors. This is especially true in the United States where there is a long tradition of state governments creating "enterprise zones" in which tax relief and other forms of assistance are granted to companies so that they locate within the jurisdiction. There is often intense competition among US states to entice firms through these initiatives with a view to stimulating the local economy by employment and infrastructure creation. ${ }^{99}$

The cycle of FDI regulation capturing investment incentives, as well as their withdrawal, has been alluded to by commentators. While initially being neutral or even hostile to foreign firms, host states move to promote FDI aggressively (the so-called "Red Carpet" stage), following which they engage in a period of prolonged privatization, after which the

large emerging economies, much of which has been achieved as a consequence of promotional efforts by home states).

96 K.P. Thomas, Investment Incentives and the Global Competition for Capital (Palgrave MacMillan, New York 2011) Ch 7.

97 S. James, 'Tax and Non-Tax Incentives and Investments: Evidence and Policy Implications' (World Bank Investment Climate Advisory Services, Washington DC September 2013).

98 Muchlinski (n 21) 32-3.

99 A. Peters, Industrial Incentives: Competition Among American States and Cities (Upjohn Institute, Kalamazoo, MI 2001). 
presence of foreign firms begins to raise suspicion and ultimately resistance. This phase is characterized by the revocation of rights that had once been used to encourage FDI but now appear excessive or even indicative of corruption. The next stage is therefore one in which the level of FDI declines. ${ }^{100}$ Studies have shown that MNEs have become more responsive to locational incentives, such as tax breaks and free factory space, and that competition between developed and developing countries to attract FDI through these initiatives is intensifying. ${ }^{101}$ Comprehensive data on the usage of investment incentives remains elusive, despite incentives' status as some of the most important policy tools employed by countries engaging in FDI. ${ }^{102}$

\section{(ii) Justifications}

The use of FDI incentives can be explained by reference to information asymmetry the foreign firm and the host state, with the investor often unfamiliar with the regulatory environment in the host state and the state uncertain as to the precise benefits that the foreign investor can bring to its economy. Furthermore, shortcomings in the investment climate in the host state can be problematic. This can include deficiencies in the infrastructure, a poorly trained workforce and weak domestic governance, including rule of law and protection of private property. As such, the incentive is well-described as a tool of risk mitigation.

The economic rationale for providing incentives to foreign firms is to capture the spillovers associated with FDI, meaning advantages accruing to the wider economy of the host state beyond the recipient firm. In that sense, the benefits of incentives are those that are typically associated with FDI itself, including employment, the transfer of firm-specific assets to the host jurisdiction (such as factories, as well as intellectual property), managerial expertise and technological advancement and the stimulation of competition. These are often described as the "dynamic" effects of FDI, such as the technological improvements to the domestic industry and cost reductions by local firms resulting from gaining know-how through exposure to the production activities of foreign partners or even competitors. Foreign firms can attract anchor investments or clusters, providing multiplier effects by signalling economic prosperity and through the creation of backward linkages in the form of purchase or supply arrangements with the local economy. Many of these positive

\footnotetext{
100 Walde and Kolo (n 91) 309.

101 Moran (n 92) 293.

102 Subrahmanyam (n 81) 301.
} 
externalities create more value to the host country than they do to the investing firm.

If the profits available to foreign investors are not sufficiently high, then the investor will choose not to locate in the host state and these benefits will be lost. Accordingly, incentives intend to account for the difference between private and social rates of return - encouraging socially productive investment that would not have occurred on a purely private, that is, firm level assessment. ${ }^{103}$ Incentives have the potential to contribute to an efficient allocation of resources where market prices and private self-interest does not fully capture social benefits. As such, investment incentives may be viewed as an appropriate instrument of governmental policy for the correction of market failures, or, put another way, to address non-market needs, providing benefits for a state or its citizens that are not captured by market transactions. Some examples of this include cultural preservation and environmental protection. ${ }^{104}$

The continued support for FDI incentives by host countries suggests that investment incentives are effective in attracting FDI and that FDI in turn helps achieve economic goals.

Investment incentives remain important for national policymakers seeking to promote local production and employment. Some countries which operate highly focused investment incentive regimes, such as those directed at technology, have implemented these successfully. For example, the investment incentive schemes employed by Austria and Czech Republic have been effective because they are focused on projects that emphasized training of employees and the diffusion of technology as well as efforts to stimulate the development of underperforming regions. ${ }^{105}$ The donation of greenfield land to encourage foreign automobile companies to invest was a helpful strategy for Romania, which managed to extract technological know-how from several European firms in the late 2000s. ${ }^{106}$ Disregarding the effects of FDI on employment,

103 S. James (n 97).

104 D. Petrov, 'Prisoners No More: State Investment Relocation Incentives and the Prisoners' Dilemma' (2001) 33:1 Case Western Reserve Journal of International Law 71, 74.

105 'Investment Incentives: The Good, The Bad and the Ugly' (Vale Columbia Center on Sustainable International Investment (13-14 November 2013) 27, citing World Bank Investment Climate Advisory Services (2013) <http:// ccsi.columbia.edu/files/2014/01/VCC_conference_paper_-_Draft_Nov_12.pdf> accessed 13 March 2015.

106 K. Hope and T. Troev, 'Manufacturing: Autos Emerge as Driving Force' Financial Times (London, 4 December 2012). 
which are often difficult to measure because workers employed by foreign firms may have eventually found work at domestic firms, there is strong evidence that FDI leads to higher productivity in industrialized countries. Observed spillovers tend to be enjoyed by other firms located close to the site of foreign direct investment and in the same industry, typically with a similar level of overall technology. ${ }^{107}$ One study has shown that sectors targeted by investment-promotion initiatives received twice as much FDI as those sectors which did not receive the promotional assistance and twice as much in the same sector than before the initiatives were instigated. ${ }^{108}$

Incentives may be used to compensate for an unfavourable policy environment in the host state. In developing countries in particular, a significant number of economic activities are either totally controlled by the government or else heavily regulated. In heavily regulated countries, such policies may themselves be viewed as a market distortion; in which case, incentives may be viewed as a corrective device, allowing firms to achieve favourable returns. As such, incentives have a compensatory function. Incentives attempt to achieve some or all of these goals by increasing the rate of return, reducing or redistributing the costs and risks associated with an investment. ${ }^{109}$ It can be difficult for over-regulated or high-risk countries to attract FDI in the absence of a structured investment incentive program, particularly in the wake of high profile political upheavals and persistent civil unrest. ${ }^{110}$ Countries with a high level of political risk tend to be more likely to use investment incentives as a means of attracting FDI, with incentives compensating for greater risk. ${ }^{111}$ The presence of an investment incentive may act as a signal to foreign firms that the donor state is business friendly or that it is eager to provide

107 X. Liu, P. Siler, C. Wang and Y. Wei, 'Productivity Spillovers from Foreign Direct Investment: Evidence from UK Industry Panel Data’ (2000) 31 Journal of International Business Studies 407-25.

108 T. Harding and B. Javorcik, 'Roll Out the Red Carpet and They Will Come' 72 Columbia FDI Perspectives 18 June 2012.

109 Subrahmanyam (n 91) 303.

110 For example, Egypt had difficulty attracting FDI after its revolution in January 2011: I. Kottasova, 'Czechs in Egypt's First Post-Mubarak Foreign Direct Investment' Financial Times (London, 21 September 2011).

111 Y. Zheng, 'Credibility and Flexibility: Political Institutions, Governance and Foreign Direct Investment' (2011) 37:3 International Interactions: Empirical and Theoretical Research in International Relations 293-5 (observing a high correlation between political risk and FDI incentives). 
an environment that is conducive to commercial profitability, even if there is less tangible indication of this. ${ }^{112}$

One of the chief advantages of investment-promotion programs is mitigating information and communication barriers. ${ }^{113}$ Perhaps most interesting, investment-promotion efforts tend to work best in terms of attracting FDI in countries with less effective governments, higher corruption and a greater number of administrative hurdles involved in commercial activities. ${ }^{114}$ As such, the chief advantage of investmentpromotion schemes may be seen as the reduction of red tape, the degree of which is captured by indicia such as the World Bank's annual Doing Business reports.

Investment incentives are often used to counterbalance performance requirements, with some countries using a combination of both performance requirements and investment incentives to control the nature and extent of inward FDI, with investors forced to accept both as part of an overall package of conditions. ${ }^{115}$ Studies have shown that a firm's receptiveness to investment incentives is dependent on the stage that it is in during its life-cycle, and the extent to which the incentive that is offered matches its needs at that moment. Newer firms may seek incentives that lower their initial expenses during the start-up phase, whereas more established firms wishing to internationalize are more likely to prefer taxoriented incentives that will raise their profits. Investors at all stages of their life cycle want incentives that are transparent and understandable. Certainty in investment incentives is highly valued by foreign investors, as this facilitates forward planning and capital acquisition. ${ }^{116}$

\section{(iii) Criticisms}

Like classic trade-oriented subsidies, investment incentives tend to be economically inefficient. The utility of investment incentives as part of the economic strategy of a country is tied to the benefits that are engendered by FDI, which are by no means certain. For example, foreign

\footnotetext{
112 Petrov (n 104) 80.

113 Harding and Javorcik (n 108). This study involved US investors, so it could be concluded that the same effects would be observed wherever the host state's language and culture differs from that of its inward investors.

114 ibid.

115 S. Amarasinha and J. Kokott, 'Multilateral Investment Rules Revisited' in F. Ortino and C. Schreuer (eds), Oxford Handbook of International Investment Law (OUP, Oxford 2008) 145.

116 James (n 97).
} 
firms may use fewer domestic inputs than the equivalent domestic firm and employment opportunities may be limited to those which do not enhance the skills of workers. Furthermore, foreign firms may repatriate rather than re-invest their profits, meaning that much of the economic benefits may be enjoyed by their home state. This is particularly the case in the extractive industries, where profits tend to be more readily sent to shareholders in the home state after up-front capital expenditures have been made. Such strategies will dictate the nature of incentive packages offered by host states to various industries, often in conjunction with performance requirements to maximize the beneficial impacts on the host economy. ${ }^{117}$

The chief drivers of inefficient incentives are asymmetries in information among many target countries and inequality of bargaining power between the host state and the foreign firm. Host states are often at an informational disadvantage regarding the expected benefits of an FDI project relative to the investor itself. When they are unable to ascertain the investor's capabilities or intentions such information asymmetry can lead to host governments paying too much for investment or granting redundant incentives, meaning that incentives do not feature in the investor's decision to invest. Governments often do not know what incentive schemes are being offered by competing jurisdictions, just as large MNEs are often better able to assess the economic impacts of their investments than host states. Smaller states may not have the capacity to negotiate with large MNEs as to the specific conditions, such as performance requirements, that may be provided in conjunction with a tailored incentive scheme, allowing the MNE to seek exploitative packages. Such asymmetries can be exacerbated by the increasing use of site consultants: individuals who are hired by firms or governments to assess the impact of an investment project and which may misrepresent estimates.

Clearly there are both direct and indirect costs associated with fiscal incentives. The direct costs of a fiscal incentive are the revenue losses that occur as a result of the state granting tax benefits to a foreign investor that would have invested even without the incentive. The indirect costs are often more difficult to measure but can be numerous. There may be market distortions that result from encouraging new investments that undermine the success of existing ones. Firms often spend much time and money in lobbying the government for incentives, which may not be recovered. If the incentives are conditional on firms fulfilling certain

117 Vale Columbia report (n 105) 11. 
goals, such as those linked to employment or location, the resources expended satisfying these conditions can be considerable. Tax exemptions may lead to illegal behaviour, where firms that do not qualify for the incentive present false information in order to do so. This can in turn represent government expenditures in investigation and enforcement, not to mention the ongoing cost to governments of administering the incentive scheme.

It is far from certain that FDI incentives are actually effective in inducing foreign investors to locate within the offering state. It is also not clear that FDI itself actually achieves many of the economic benefits with which it is associated. Many factors will influence a firm's decision on where to locate its operations. These can include the natural endowments of the host state and the size of the local market, the skills of the labour force, political stability, the extent of the infrastructure and the quality of the regulatory environment, including regard for private property. A majority of studies indicate that investment incentives play a limited role in investment decisions, and as such they generally fail to stimulate economic growth. ${ }^{118}$ Firms which internationalize in order to enter new markets or to acquire raw materials or strategic assets are less inclined to make locational decisions on account of incentives than more mobile and efficiency-seeking firms aiming to reducing costs for products destined for global rather than domestic markets. ${ }^{119}$ One survey indicated that incentive packages ranked very low in terms of the factors influencing a firm's locational decision. Economic stability, political stability, costs of raw materials, the local market, transparency of business regulations and legal framework, availability of skilled labour, labour costs, quality of life and the availability of local suppliers were seen as more important for investors. ${ }^{120}$ The IMF and the World Bank also tended to advise countries against offering FDI incentives, because they are largely ineffective in achieving economic growth and because a country's institutional infrastructure is a more important determinant in MNE's location decisions than a country's incentive regime. ${ }^{121}$

Exemptions from income tax are heavily criticized by economists. One of the reasons for this is that when tax holidays are granted, the

\footnotetext{
118 See Petrov (n 104) 79.

119 Vale Columbia report (n 105) 16.

120 'Africa Investor Report 2011: Towards Evidence-Based Investment Promotion Strategies' (UNIDO, 2011) <www.unido.org/fileadmin/user_media/ Publications/Pub_free/AIS_Report_A4.pdf> accessed 2 December 2014.

121 J. Stotsky, 'Summary of IMF Tax Policy Advice' in P. Shome (ed.), Tax Policy Handbook (International Monetary Fund, 1995) 292-82.
} 
assessment of the amount of tax revenue that a government will forgo can be problematic. Moreover, income tax holidays tend not to be associated with conditions that could be beneficial for the host state, such as local employment quotas or mandatory reinvestment of earnings. As such, this type of incentive tends not to be paired with a foreign investor's performance requirement. This type of incentive does little to prevent an early departure of the foreign investor when its profits increase relative to the tax revenue that the government has exempted it from. There may come a point where the value of staying in a jurisdiction evaporates as the level of exempted tax becomes insignificant. Tax holidays generally appeal to high profit investment - those where there is major tax liability - rather than those in an early or exploratory phase of their development. FDI-oriented tax incentives work to attract FDI in a minority of instances. ${ }^{122}$

Consequently, there may be a strong likelihood that the MNE would have made the investment in the relevant host state irrespective of the income tax exemption. FDI-oriented tax incentives appear to work to attract FDI in a minority of instances. ${ }^{123}$ An additional concern is that tax holidays can lead to more situations where there has been transfer pricing - a strategy by which firms artificially segregate the profit-generating features of their activities to low income tax jurisdictions, an arrangement which can deprive the host state of significant revenue. This is particularly problematic where the foreign investor transfers the profit generating aspects of its business back to its home jurisdiction - effectively channelling the greatest part of its tax out of the host state and in so doing undermining one of the central premises in support of FDI. Such strategies are likely one of the reasons that many countries have actively pursued outward FDI support programmes. ${ }^{124}$ Studies have shown that, when FDI is supported by regional aid from the host government, firms are more likely to locate in less economic and prosperous areas, but that their location decision is contingent on ongoing financial aid from government. Accordingly, the entry of FDI does not usually create a self-sustaining local economy. ${ }^{125}$

122 The McKinsey Report (2003), as discussed by A. Beattie, 'Report Casts Doubt on FDI Incentives' Financial Times (London, 15 October 2003).

123 ibid.

124 Vale Columbia report (n 105) 55.

125 C. Wren and J. Jones, 'Assessing the Regional Impact of Grants on FDI Location: Evidence from UK Regional Policy, 1985-05' (2011) 51 Journal of Regional Science 497. 
In addition to their dubious economic benefits for the states that impose them, these types of international economic policy tools are criticized for their discretionary and secretive nature. ${ }^{126}$ Investment incentives often reflect political machinations, in as much as the economic advantages they entail are disproportionate to their costs, or the benefits to be gained are distributed unevenly, typically on the basis of perceived political advantage. From a political standpoint, extending investment incentives only to foreign firms tends to please small interest groups who benefit disproportionately from FDI. These are likely to be domestic suppliers, distributors or partners of foreign investors. These groups are more likely to dominate when institutional factors are weak, such as a democratically elected government and independent courts. This explains why foreign-only incentives tend to be higher in countries with poor governance than in countries that have stronger institutions. ${ }^{127}$ When political institutions are robust, governments are more likely to offer broad based incentives that benefit the economy at large.

Failure to ensure that investment incentives are dispensed in a transparent manner can lead to an invidious situation of disguised favouritism or cronyism. ${ }^{128}$ Studies conducted in the US have demonstrated that investment incentives allow politicians to take credit for firms' decisions to locate in specific areas. Similarly, failure to provide adequate incentives allow politicians to minimize the blame associated with firms' decisions to leave the jurisdiction. ${ }^{129}$ Regardless of their effects on either national or global economies, because of their strong political overtones, investment incentives also represent an opportunity for government corruption. Governmental officials entrusted with wide discretionary powers could enact legislation offering assistance to foreign firms in order to advance their own personal or business interests, irrespective of whether the assistance is in the public interest. ${ }^{130}$ Even in the absence of

\section{Picciotto (n 47) 163.}

127 Y. Zheng, 'Credibility and Flexibility: Political Institutions, Governance and Foreign Direct Investment' (2011) 37:3 International Interactions: Empirical and Theoretical Research in International Relations 293-5.

128 As has been associated with India, for example: A. Dubey, 'Key Tasks for a Strong Modi Government' Financial Times (London, 15 May 2014).

129 N. Jensen, E. Malesky, M. Medina and U. Ozdemir, 'Pass the Bucks: Investment Incentives as Political Credit-Claiming Devices: Evidence from a Survey Experiment' (Working Paper, Washington University in St Louis, 30 June 2010) <https://pages.wustl.edu/files/pages/imce/nathanjensen/passthebucks workingpaper.pdf $>$ accessed 2 December 2014.

130 A. Nov, 'The "Bidding War" to Attract Foreign Investment: The Need for a Global Solution' (2005) 25 Virginia Tax Review 835, 842-3. 
full-on corruption, the need to earn the support of influential interest groups may be viewed as a subversion of the democratic process, particularly in jurisdictions with a strong lobbying culture or without sufficient safeguards against political donations.

It is widely recognized that financial incentives are a direct drain on government budgets. Tax incentives diminish the tax base, depriving the host state of revenue, but also complicate tax administration. There can be significant costs associated with designing and implementing a coherent investment-promotion strategy or establishing an investmentpromotion agency. Even improvements in transparency can place significant burdens on states with limited resources. ${ }^{131}$ In some instances, incentives are given for investments in which there are carrying costs that governments themselves are not in a position to manage due to limited resources. Such costs are foisted onto foreign investors, who are in turn compensated through incentives. ${ }^{132}$ This explains why they are not offered by developing countries. It can also represent serious financial costs to governments. It is often thought that the country which wins the incentive bidding war and ultimately attracts the foreign firm is most probably the one that has held the most unrealistically optimistic view of the benefits likely to be achieved. ${ }^{133}$ A state that grants an incentive may have fewer resources to spend on education or infrastructure, which may render it less appealing to investors seeking skilled employees or a sophisticated transportation network. It may also result in a waste of governmental funds that would have been better deployed elsewhere because the benefits associated with FDI may be negated by the cost to the government of providing the incentive in the first place. ${ }^{134}$

Often the presence of an incentive indicates that there is an absence of strict regulations in many spheres, which can be attractive to foreign firms. This can in turn lead to the potential for environmental degradation and abuse of employees. Investment incentives may encourage investment, but the nature of the incentive may lead the investor to behave in undesirable ways when it is engaging in its investment project. For example, government subsidies on inputs such as water and electricity may cause the investor to waste resources or worse, prevent them from

\footnotetext{
131 VanDuzer et al. (n 24) 495.

132 Subrahmanyam (n 91) 302.

133 M. Daly, 'Investment Incentives and the Multilateral Agreement on Investment' (1998) 32:2 Journal of World Trade 5, 6.

134 Amarasinha and Kokott (n 115) 145.
} 
implementing the very technologies that had made them attractive as investors in the first place. ${ }^{135}$

There can be a misalignment of the costs and benefits associated with investment incentives with the benefits of an investment project being captured by the government in office at the time, with the costs foisted onto future governments - a situation which can be worsened if inappropriate discount rates are used to gauge future impacts. The cost-benefit calculus can be problematic where there is no counterfactual that can be properly evaluated: the government cannot know what would have happened had the particular incentive package that it offered had not been offered, or if it had been less generous. Difficulties in setting the optimal incentive scheme to attract investors may be inevitable as a consequence of the increasing mobility of capital, meaning that even where attractive incentive packages are granted, global firms may easily locate elsewhere to respond to a more desirable scheme in another location after a short period of time. ${ }^{136}$

In a competition among host states to attract foreign investment, the state that succeeds may achieve short-term benefits, but this may be unnecessarily costly. The government is forced to offer a package that is better than that of other jurisdictions or else it will lose the competition. This could create a situation in which the use of investment incentives becomes normalized, conferring an advantage on investors at the expense of the general welfare. As such, competition for incentives may be described as a problem of collective action. This is a situation where multiple individuals would benefit as a group from a certain choice, but this choice has a cost which makes it irrational for any one individual to bear and resolve on its own. The action should be undertaken in a manner in which the cost of the action is shared by all. An individual government does not wish to limit its capacity to employ incentives to achieve an advantage over a competing jurisdiction where there is no indication that other jurisdictions have shown any willingness to restrain their own use of these tools. The self-interest of each state encourages a "race to the bottom" towards the most generous and often excessive incentive packages - playing into the hands of the foreign firms. ${ }^{137}$

At a global level, the proliferation of various varieties of investment incentives may severely distort the global distribution of FDI without necessarily increasing its total supply. Consequently, the main argument

\footnotetext{
135 Salacuse (n 14) 102-3.

136 Vale Columbia report (n 105) 73-4.

137 Thomas (n 96) ch 2.
} 
against the use of investment incentives as mechanisms to attract foreign investment is that they can lead to FDI going to jurisdictions where it achieves less utility from an efficiency perspective. The international dimension of investment incentives is controversial, because of the understanding that host state assistance for foreign investors represents a form of international competition that can lead to damaging outcomes. The OECD in particular has described the strategy of seeking to outdo other countries in offering the most attractive incentives as one that is individually rational; but on a collective, global scale there are unintended consequences, namely subsidization of inefficient firms to the detriment of public resources. ${ }^{138}$ Some countries are pressured into offering assistance packages to foreign investors that they would not otherwise extend out of fear that the investor will lose interest and go elsewhere. As such, the offering of incentives for FDI is a classic example of the race to the bottom scenario. Bidding wars among jurisdictions to appeal to the best firms through increasingly generous incentives (notably tax relief) have been condemned by commentators as a serious market distortion in which governments overpay - meaning that they offer more in incentives than they ultimately gain by way of economic advantage, leading to the so-called "winner's curse". 139 The state that manages to succeed in attracting the foreign investor tends to be the one that has offered the most in concessions, which may ultimately be damaging relative to the gains that the foreign investor can offer because such generous packages are required to beat out other jurisdictions, even if this may seem to be economically irrational behaviour. Losing states also suffer because they often expend resources in courting investors that are never recovered. States compete for investors, rather than the opposite, because there are comparatively few large investors compared to the number of governments who seek them, especially when sub-national governments are considered. ${ }^{140}$ In the words of the OECD: "competitive investment incentives support industries for political rather than economic reasons ... they tend to be offered to the most mobile producers and not to 'captive' producers". ${ }^{141}$ In other words, governments tend to offer incentives to firms that are in a position to pick and choose

138 OECD, 'Incentives-Based Competition for Foreign Direct Investment: The Case of Brazil' (OECD Working Papers on International Investment No. 2003/1, 2003) 8.

139 Nov (n 130) 842-3.

140 K. Thomas, 'EU Control of State Aid to Mobile Investment in Comparative Perspective' (2012) 34:6 European Journal of Integration 567, 570-71.

141 OECD (n 138) 10. 
among target destinations, not to firms that would be willing to make long term commitments to the host state, or which may already be located there and would therefore be unwilling to bear the cost of re-locating. There is clear evidence that "incentive competition", as it is often termed, does take place, although much of the research into this phenomenon has focused on regional competition at the sub-national level within particular countries. ${ }^{142}$ The economic integration brought about by globalization is believed to have tightened the conditions of competition for FDI, creating a situation in which countries rush to establish tailor-made packages to attract foreign investors, rather than by establishing a favourable business environment in the long term. Much of these initiatives are non-transparent, meaning that they are arranged bilaterally between host governments and target companies with little input from the electorate or through open competition. ${ }^{143}$

Developing countries are often in direct competition with wealthier countries for a particular investment. There are often situations where developing countries end up offering much more generous incentives than those paid for in developed countries. The unfortunate consequence of such arrangements is the reduction of available resources for infrastructure and education. It is often asserted that the capacity to offer such advantages to foreign firms privileges wealthier countries, some of which are able to extend public funds to support research and development or to make sure that the foreign investors operations are located in a region of high unemployment. Poorer states are often relegated to extending incentives in the form of tax relief or generous depreciation allowances which, unlike direct grants, do not require an immediate expenditure even though they diminish future government revenue. ${ }^{144}$

Finally, as the protections enshrined in IIAs are viewed as a form of incentive that minimizes some of the risks associated with FDI, criticisms levied at these instruments should be noted. Chief among these is the allegation, of particular relevance in conjunction with the ongoing negotiation of the Transatlantic Trade and Investment Partnership (TTIP), that investor-state dispute settlement is unfairly discriminatory against local investors because it offers a means of dispute settlement that is available only to foreign firms. This has been depicted by some as a

142 Predominately among US states: see e.g. M. Taylor, 'A Proposal to Prohibit Industrial Relations Subsidies' (1994) 72 Texas Law Review 669.

143 L. Oxelheim, 'EU-China and the Non-Transparent Race for Inward FDI' (2008) 19:4 Journal of Asian Economics 358.

144 Picciotto (n 47) 163. 
violation of the principal of equality before the law. ${ }^{145}$ The potential for massive damages awards levied against host states, some of which are ill-positioned to satisfy them because of their developmental status, is similarly problematic both from a perspective of global equity as well as questionable incentive strategy for states seeking beneficial FDI.

\section{CONCLUSION}

The nature and purpose of performance requirements and investment incentives as applied by host states in conjunction with their regulation of foreign investment presents a complex picture of numerous advantages and drawbacks, some of which cannot be readily quantified and which remain a source of debate for economists and politicians. Their implementation requires the careful consideration of various competing policies, including the need to stimulate FDI while ensuring that the ensuing competition does not adversely affect the local economy. Negotiation over the FDI incentives and any conditions imposed thereon between host states and firms can be fraught with information asymmetries often resulting in a situation in which the government ends up surrendering more than it gains. From a regulatory standpoint, investment incentives, whether conditional or traditional, can risk discriminating against certain firms based on their nationality, compromising one of the central pillars of international economic law. It is this second issue that will be the focus of the next chapter.

145 Speech by J.C. Juncker, Strasbourg, 22 October 2014. 